\title{
Quality of life and neuropsychomotor development of infants between 4-18 months in daycare center
}

\author{
Qualidade de vida e desenvolvimento neuropsicomotor de bebês \\ de 4-18 meses em centros de educação infantil
}

Tainá Ribas Mélo (https://orcid.org/0000-0002-7630-8584) ${ }^{1}$

Luize Bueno de Araujo (https://orcid.org/0000-0001-9795-4043) ${ }^{1}$

Bruna Yamaguchi (https://orcid.org/0000-0003-1352-3399) ${ }^{1}$

Manoela de Paula Ferreira (https://orcid.org/0000-0003-3446-7752) ${ }^{1}$

Vera Lúcia Israel (https://orcid.org/0000-0001-5824-7792) ${ }^{1}$

${ }^{1}$ Programa de Pós-

Graduação em Educação

Física, Universidade Federal do Paraná. R. Coração

de Maria 92, Campus

Jardim Botânico. 80210-

132 Curitiba PR Brasil.

ribasmelo@gmail.com

\begin{abstract}
Quality of Life (QoL) is a predictor of development depending on multiple factors, being the QoL of infants still little studied, especially in permanent settings such as infants educational center or daycare centers. Correlate quality of life with age, family income and the neuropsychomotor development of infants between 4 and 18 months of age in daycare centers. Descriptive transverse study research, with clinical trials registration: RBR 2hd6sm on November 2, 2016. Quality of life was evaluated with interviews with the family through Pediatric Quality of Life Inventory-PedsQL $L^{\mathrm{TM}}$ (Brazilian version). The infants were evaluated in a playful way, through the use of Alberta Infant Motor Scale (AIMS) and Denver II test. 88 infants participated in the study. The infants evaluated had a good quality of life, with scores above 64\%. AIMS presented the correlation with for physical functioning and total score of QoL. QoL of infants from 4 to 18 months of age is correlated with their neuropsychomotor development, which suggests the need for investigations between this theme and daycare centers. Key words Infant, Quality of life, Day care center, Infant development
\end{abstract}

Resumo Qualidade de vida (QV) é um preditor de desenvolvimento e depende de múltiplos fatores, sendo a QV de bebês ainda pouco estudada, especialmente em ambientes de permanência como os centros de educação infantil ou creches. Correlacionar a qualidade de vida com idade, renda familiar e desenvolvimento neuropsicomotor de bebês entre 4 a 18 meses de idade que frequentam centros de educação infantil. Pesquisa descritiva transversal, com registro clínico RBR 2 hd6sm em novembro de 2016. A Qualidade de Vida foi avaliada por meio de entrevistas com as famílias com o questionário Pediátrico de Qualidade de Vida-Peds $Q L^{\mathrm{TM}}$ (versão brasileira). Os bebês foram avaliados de maneira lúdica pela escala motora infantil de Alberta (AIMS) e pela Denver II. 88 bebês participaram do estudo. Os bebês avaliados tiveram uma boa qualidade de vida com escores acima de 64\%. AIMS apresentou correlação com os escores de capacidade física e escore total de qualidade de vida. Qualidade de vida de bebês de 4 a 18 meses de idade correlacionam-se com seu desenvolvimento neuropsicomotor, sugerindo a necessidade de investigações sobre esse tema em centros de educação infantil.

Palavras-chave Bebês, Qualidade de vida, Centros de educação infantil, Desenvolvimento infantil 


\section{Introduction}

Quality of Life (QoL) is a predictor of development and embraces components of well-being, in an ecological perspective, depending on multiple factors, such as familiar and social relations, economic conditions, among others; it can be considered subjectively or objectively ${ }^{1,2}$. When it comes to very young children, self-reports are not possible, and parents or the closest caregivers are the most indicated to identify and quantify these $^{3}$. The construct which opposes the evaluation of QoL in this age focuses on the current moment of the child, differing from adults that have plans and future perspectives which involve personal QoL ${ }^{4}$.

Today, it is believed that neuropsychomotor development (NPMD) on children is a result of the influence of multiple systems and extrinsic factors related to environment and task, in a nonlinear manner, with critical periods of development. This is what guides current conceptions and studies ${ }^{5}$. Among these factors, the social-economic condition also shows influence upon NPMD ${ }^{6}$. Today, as consequence of an amplified vision over health and International Classification of Functioning, Disability and Health$\mathrm{ICF}^{2}$, the concept of well-being, related to QoL, contributes to a plain NPMD. To evaluate QoL in this stage of life, multifactorial instruments ${ }^{4}$ are used. In the current literature no studies about QoL of infants have been found.

In this context, in infants' NPMD, both question of family context and the daycare merit a feature in the identification of risks to development ${ }^{7}$. Daycares or CECs (Children Educational Center) constitute spaces that receive children from 0 to 3 years old and pre-scholars from 4 to $6^{8}$.

In these spaces, teachers/caregivers may be considered the first social connections of the child ${ }^{9}$. Daycare as a related context to development raised with the insertion and increasing participation of women in the job market, because it is the main alternative for the care of infants and children ${ }^{10}$.

In these places, since children are there for long periods of time, they cease to have an assistencialist character and start growing relevance in education and NPMD stimulation with parents and caregivers ${ }^{11}$. Therefore, since they may bring consequences on potential to the adulthood and to the country's economy (every dollar invested in NPMD may later represent a decrease of 8 to 14 dollars in its cost), they started to be considered investigation spaces ${ }^{12}$.
Considering interfering factor on QoL as outcomes that must be considered on ICF's perspective $^{13}$, the Pediatric Quality of Life Inventory $\left(\right.$ Peds $\left.\mathrm{QL}^{\mathrm{TM}}\right)$ of infants presents validation and reliability to be used both with healthy children, as well as the ones with diseases or atypical development ${ }^{3}$. However, in very young children, a self-report is not possible and the family and/or caregivers are the ones indicated to assist on the identification and quantification of these components ${ }^{3}$.

This instrument has versions according to age and health condition. To infants, it's presented the 1-12 months old version and another one for 13-24 months old, performed through interviews of parents and caregivers ${ }^{3}$. Most of the articles use this scale when pathologies exist.

Although it's common understanding that environmental and external influences have power over NPMD, yet there are many questions without answer and low investigative relevance seems to be given to infants's QoL (typical or in development risk at daycare environment).

Therefore, the goal of the present research was to correlate the QoL with age, family income, and NPMD of 4 to 18 months old infants that are in daycare at full time.

\section{Methods}

This is a descriptive transverse study, approved by Federal University of Paraná committee of ethics, with retrospectively clinical trials registration of RBR 2hd6sm at 2 November 2016, and composes part of a bigger Brazilian study by public name of "Alegria em Movimento: intervenção precoce para crianças" (Portuguese name for "Joy on the Move: Early Intervention for Children"). This characterization was performed from June to July of 2016, with selection of participants made for convenience.

Four authorizations for application for the study in daycares were granted by the Secretary of Education of a city of Paraná, also denominated CECs. The four CECs were public, and the CECs 1 and 3 had a co-participation in the monthly payment given by the parents according to their income, whereas the CECs 2 and 4 were fully subsidized by the government.

Inclusion criteria for the study interview were infants of both genders ${ }^{14}$, between 4 and 18 months old, frequenting daycare at full time for at least two weeks, and allowed by parents or accountable through an Informed Consent Form. 
Since there is evidence that the gender will not influence the NPMD in the first 24 months of life $^{14}$, the gender will not be considered an analysis variable.

The exclusion ${ }^{15}$ was: infants with congenital malformations (musculoskeletal) that presented any signs of neurological deviance (seizures, nervous system infections, neonatal asphyxia, nervous system bleedings, atypical reflexes ${ }^{16}$ ), genetic syndromes, sensorial deviance, infants with history of congenital infections (STORCH-HIV) diagnosed during neonatal period ${ }^{17}$, malformations that may influence the expression of speaking, visual and/or auditory deviance ${ }^{18}$.

All the parents and/or closest family member of the infants that were in the baby nursery of daycares were invited to receive explanation about the research. After the acceptance to participate the research, all the parents and/or closest family member were interviewed by the same evaluator, a Physiotherapist. The process of data gathering was divided in two steps: the first was performed with the parents directly and lasted 30 minutes in average, and second was performed with the infants, also directly.

\section{1st Step: interviews with the parents}

Anamnesis report with: born date, parent's names, weight and height when born, gestational age (GA), data about the delivery and lor intercurrences, existence of diseases (previous or old or actual). Besides that, data about parents' schooling, age, economical aspects (the Economic Classification Criteria Brazil 2012, proposed by the Brazilian Association of Research Companies-ABEP ${ }^{19}$ ) and values informed by family income.

The data about QoL were registered through individual interviews with parents or child's closest family member, through PedsQL ${ }^{\mathrm{TM}}$ survey, Brazilian version, 1-12 and 13-24 months. The score goes from 0 to 4 and then it is transformed in a percentage. The higher the percentage, the better the child's QoL is ${ }^{3,20}$.

\section{2nd Step: evaluation of the NPMD of the infants}

All the infants of both genders were evaluated through motor and psychomotor scales in a ludic way: Alberta Infant Motor Scale (AIMS) and Denver $\mathrm{II}^{21}$ after a 2 week familiarization between researcher and infants.

Denver II scale is a valid instrument ${ }^{22,23}$, and is the most used screening test in Brazil ${ }^{18}$, it allows psychomotor evaluations in motor functioning (gross and fine), personal-social, language and cognitive-adaptable. This is a low cost, fast and of easy application test, with 20-30 minutes medium time for evaluation, through the observing of specific items for the assessed age, in each area/ domain in the scale ${ }^{24}$. This test is carried out by tracing a line and verifying which items need to be evaluated ${ }^{25}$. Four categories were considered for assessment: "passed" when the subject performed correctly; "failed" when there were errors during the execution; "refusal" when subjects refused to perform an item; and "not evaluated" when items were impossible to be examined ${ }^{24}$. It has a version with cultural adaptation for Bra$\mathrm{zil}^{22,23}$. If the child has 1 failed or 2 caution, he or she presents a questionable psychomotor profile, and, as for 2 failed or 1 failed plus 2 cautions, it is considered delay ${ }^{26}$.

As this scale is not so specific in relation to motor issues in the first 6 months of life, the infants have also been evaluated by Alberta Infant Motor Scale (AIMS) ${ }^{27}$, through observation of the child's spontaneous movements, alignment and contact surface in 4 postures (prone, supine, sitting and standing), with no restrictions, no handling and/ or facilitations ${ }^{28}$. That protocol is low cost and of an easy application, consisting of directly observing the child, with 30-40 minutes of duration ${ }^{29}$. The score was reported as passed/failed. By the end, the points in each observed posture were added in a total score of all items observed, being related to age and score to trace his/her percentile $^{28}$. It is considered a delay if the child presents $<5$ percentile; suspicious if presents $<25$ and $>$ 6 percentile; and it is typical if $>25$ percentile $^{30}$.

During the NPMD evaluation on the infants from daycare, the classroom teacher was present and toys were used in order to incentive the active performance of movements and postural changes. The infants were scored in the moment of evaluation, by an examiner who has more than 11 years of practicing the scale.

According to the evaluations, the child was considered in risk to NPMD when he/she presented suspicious or delay by AIMS, and/or questionable profile or delay by Denver II.

Firstly, it has been performed the descriptive data analysis, based on attendance calculation, percentage, medium, standard deviation, according to their nature. As there are evidences of social-economic influence ${ }^{6}$, before analyzing the QoL results among daycares, it was verified if there were any wage difference between them (Anova One-Way and Multiple comparison test), 
mainly because CEC 1 and 3 are convened and have higher financial incentives than CEC 2 and 4 , exclusively public.

As for the normality and homogeneity analysis, Shapiro-Wilk and Levene's test has been used. To compare groups in relation to quantitative variables, Anova was applied when variables involved had a normal distribution, complemented by the LSD test. When there was no normality, the non-parametric Kruskal Wallis test was applied, complemented by the DMS test.

To compare groups with respect to qualitative variables, the Chi-square test was applied. To evaluate the correlation between quantitative variables, the Spearman coefficient was obtained. When one of the variables involved was categorical (more than two categories), the Kruskal-Wallis test was applied.

For correlation, when Spearman's rho (rs) was used, considering very weak correlation if rs $<0.25$; weak if $\mathrm{rs} \geq 0.25<0.5$; medium if $\mathrm{rs} \geq 0.5$ $<0.75$ and strong if $\mathrm{rs}>0.75^{31}$. Data were analyzed in SPSS Statistics 22.

\section{Results}

A total number of 88 families were accepted to fully perform the research. Only two babies were preterm ( $>35$ weeks) and they had corrected age for evaluation.

For variables age and PedsQL ${ }^{\mathrm{TM}}$ punctuation, CEC's had a normal and homogeneous distribution $(p \geq 0.05)$. The mean age of the infants evaluated was $12.30 \pm 3.54$ months.

For the family income, the distribution was not normal and homogeneous $(\mathrm{p}=0.005)$. It is observed (Table 1) that the median income of CEC 1 and CEC 3 presented a higher value in extract and mean absolute value reported by parents, reaching values of family income higher than CEC 2 and CEC 4 (fully subsidized by the government) and this difference was significant. Because there was no correlation between family income and NPMD and PedsQL ${ }^{\mathrm{TM}}$ scores, it was not included in correlation scores in Table 2.

The gender variable was not considered for analysis, considering only its mean values. From the total evaluated infants, all CECs had infants with risk (delay and suspect or questionable) for development for $36 \%$ using AIMS score and for $31 \%$ using Denver II (mainly in the area of language and personal-social).

The delay was higher in CEC 4, which had lower family income and a lower rate of Emo- tional Functioning in PedsQL ${ }^{\mathrm{TM}}$. Comparing the PedsQL $\mathrm{L}^{\mathrm{TM}}$ scores among the CECs, there was a difference $(\mathrm{p}=0.028)$ with a lower score for the Emotional Functioning for CEC $4(\mathrm{p}=0.003)$ but not confirmed by LSD test ( $\mathrm{p}>0.05)$. There was a difference $(\mathrm{p}=0.005)$ for Peds $\mathrm{QL}^{\mathrm{TM}}$ Total Score. For other PedsQL ${ }^{\mathrm{TM}}$ variables, there was no difference among CEC's.

For all aspects of QoL analyzed, the found value was elevated, higher than $64 \%$, which indicates that the infants from the studied daycares presented good QoL.

Table 2 indicates the correlation between the variables daycare, age, NPMD and the PedsQL ${ }^{\mathrm{TM}}$ subscores, as well as its total score.

Age had not association with NPMD scores. The age was associated only with higher scores for physical symptons ( $\mathrm{rs}=0.271, \mathrm{p}=0.011$, weak effect).

The item physical functioning in the QoL scale PedsQL ${ }^{\mathrm{TM}}$ had association with physical symptoms ( $r s=0.340, p=0.011$, weak effect), with emotional function ( $\mathrm{rs}=0.253, \mathrm{p}=0.017$, weak effect), with the total score of the scale ( $\mathrm{rs}=$ $0.571, \mathrm{p}<0.001$, medium effect) and with AIMS scores ( $r s=-0.267, p=0.012$, weak effect). The item physical symptoms had association with physical functioning ( $r s=0.340, p=0.011$, weak effect), with emotional function ( $r s=0.340, p$ $<0.001$, weak effect), with the total score of the scale ( $\mathrm{rs}=0.438, \mathrm{p}<0.001$, weak effect). Emotional functioning had association with cognitive ( $r s=0.262, p=0.014$, weak effect $)$ and total score ( $r s=0.675, p<0.001$, medium effect). Social and cognitive functioning had association with total score scale of PedsQL ${ }^{\mathrm{TM}}$ ( $\mathrm{rs}=0.452, \mathrm{p}<0.001$; rs $=0.635, \mathrm{p}<0.001$, with weak effect and medium effect respectively).

AIMS was associated with PedsQL ${ }^{\mathrm{TM}}$ Total Score ( $r s=-0.221, p=0.039$ ). Denver II was associated with PedsQL ${ }^{\mathrm{TM}}$ Cognitive Functioning $(\mathrm{rs}=0.229, \mathrm{p}=0.032)$. AIMS e Denver II was associated $(\mathrm{rs}=0.589, \mathrm{p}<0.001$, medium effect).

\section{Discussion}

In this study, the daycare had no association with other observed variables, although two of the daycares are convened and presents higher financial resources, while other two are public. Probably because all daycares have medium income, with stratum between $\mathrm{C} 1$ and $\mathrm{C} 2$, and few cases with inferior values, there were no income association with the NPMD, differently from what 
Table 1. Sample Characterization.

\begin{tabular}{|c|c|c|c|c|c|c|c|c|c|c|c|c|}
\hline \multirow[b]{2}{*}{ CEC } & \multirow[b]{2}{*}{$\mathrm{n}=\mathbf{8 8}$} & \multirow[b]{2}{*}{$\begin{array}{c}\text { Age } \\
\text { (months) }\end{array}$} & \multirow[b]{2}{*}{$\begin{array}{l}\text { Family } \\
\text { Income }\end{array}$} & \multirow[b]{2}{*}{ ABEPP } & \multicolumn{6}{|c|}{ PedsQL ${ }^{\mathrm{TM}}$} & \multicolumn{2}{|c|}{ NPMD } \\
\hline & & & & & PF & PS & EF & SF & CF & TS & AIMS & $\begin{array}{c}\text { Denver } \\
\text { II }\end{array}$ \\
\hline 1 & 19 & $\begin{array}{l}12.02 \\
\pm 4.40\end{array}$ & $\begin{array}{c}3105.26 \\
\pm 1359.83\end{array}$ & $\mathrm{C} 1$ & $\begin{array}{c}83.85 \\
\pm 15.30\end{array}$ & $\begin{array}{c}82.50 \\
\pm 13.23\end{array}$ & $\begin{array}{c}76.32 \\
\pm 11.35\end{array}$ & $\begin{array}{c}89.93 \\
\pm 12.66\end{array}$ & $\begin{array}{c}67.91 \\
\pm 24.58\end{array}$ & $\begin{array}{l}80.10 \\
\pm 9.19\end{array}$ & $\begin{array}{c}63 \% \mathrm{~T} \\
32 \% \mathrm{~S} \\
5 \% \mathrm{D}\end{array}$ & $\begin{array}{c}84 \% \mathrm{~T} \\
5 \% \mathrm{Q} \\
11 \% \mathrm{D}\end{array}$ \\
\hline 2 & 30 & $\begin{array}{l}13.88 \\
\pm 3.21\end{array}$ & $\begin{array}{c}2310.11 \\
\pm 1539.63\end{array}$ & $\mathrm{C} 2$ & $\begin{array}{c}76.06 \\
\pm 13.99\end{array}$ & $\begin{array}{l}85.58 \\
\pm 8.37\end{array}$ & $\begin{array}{c}66.25 \\
\pm 11.20\end{array}$ & $\begin{array}{c}88.00 \\
\pm 13.18\end{array}$ & $\begin{array}{c}69.35 \\
\pm 17.95\end{array}$ & $\begin{array}{l}77.05 \\
\pm 7.63\end{array}$ & $\begin{array}{l}67 \% \mathrm{~T} \\
20 \% \mathrm{~S} \\
13 \% \mathrm{D}\end{array}$ & $\begin{array}{l}67 \% \mathrm{~T} \\
10 \% \mathrm{Q} \\
23 \% \mathrm{D}\end{array}$ \\
\hline 3 & 25 & $\begin{array}{l}10.10 \\
\pm 2.95\end{array}$ & $\begin{array}{c}3116.48 \\
\pm 1446.08\end{array}$ & $\mathrm{C} 1$ & $\begin{array}{c}78.33 \\
\pm 13.85\end{array}$ & $\begin{array}{c}80.70 \\
\pm 10.77\end{array}$ & $\begin{array}{c}71.58 \\
\pm 16.20\end{array}$ & $\begin{array}{c}89.45 \\
\pm 15.36\end{array}$ & $\begin{array}{c}72.22 \\
\pm 20.15\end{array}$ & $\begin{array}{l}78.46 \\
\pm 8.72\end{array}$ & $\begin{array}{l}68 \% \mathrm{~T} \\
32 \% \mathrm{~S} \\
0 \% \mathrm{D}\end{array}$ & $\begin{array}{l}68 \% \mathrm{~T} \\
16 \% \mathrm{Q} \\
16 \% \mathrm{D}\end{array}$ \\
\hline 4 & 14 & $\begin{array}{l}13.19 \\
\pm 2.50\end{array}$ & $\begin{array}{l}1740.43 \\
\pm 992.89\end{array}$ & $\mathrm{C} 2$ & $\begin{array}{c}69.84 \\
\pm 14.62\end{array}$ & $\begin{array}{c}80.00 \\
\pm 13.62\end{array}$ & $\begin{array}{c}64.14 \\
\pm 14.62\end{array}$ & $\begin{array}{c}77.05 \\
\pm 25.86\end{array}$ & $\begin{array}{l}57.19 \\
22.75\end{array}$ & $\begin{array}{l}69.64 \\
\pm 8.87\end{array}$ & $\begin{array}{l}50 \% \mathrm{~T} \\
21 \% \mathrm{~S} \\
29 \% \mathrm{D}\end{array}$ & $\begin{array}{c}57 \% \mathrm{~T} \\
0 \% \mathrm{Q} \\
43 \% \mathrm{D}\end{array}$ \\
\hline$P$ value & & $0.004^{*}$ & $0.005 \#$ & $>0.05$ & 0.065 & 0.447 & $>0.05^{\star \star}$ & 0.427 & 0.189 & $0.005^{\star}$ & & \\
\hline Medium & & $\begin{array}{l}12.30 \\
\pm 3.60\end{array}$ & $\begin{array}{c}2527.45 \\
\pm 1473.06\end{array}$ & & $\begin{array}{c}77.40 \\
\pm 14.76\end{array}$ & $\begin{array}{c}82.64 \\
\pm 11.16\end{array}$ & $\begin{array}{c}69.60 \\
\pm 13.88\end{array}$ & $\begin{array}{c}87.09 \\
\pm 16.61\end{array}$ & $\begin{array}{c}67.92 \\
\pm 21.13\end{array}$ & $\begin{array}{r}76.93 \\
\pm 9.00\end{array}$ & $\begin{array}{l}64 \% \mathrm{~T} \\
26 \% \mathrm{~S} \\
10 \% \mathrm{D}\end{array}$ & $\begin{array}{c}69 \% \mathrm{~T} \\
9 \% \mathrm{Q} \\
22 \% \mathrm{D}\end{array}$ \\
\hline
\end{tabular}

CEC = Children's Educational Center; SD = Standard Deviation; Min = minimum; Max= maximum; ABEP = Brazilian Association of Research Companies; PF = Physical Functioning; PS = Physical Symptoms; EF = Emotional Functioning; $\mathrm{SF}=\mathrm{Social}$ Functioning; $\mathrm{CF}=$ Cognitive Functioning; TS = Total Score; T = Typically; S =Suspect; Q =Questionable; D = Delay. P value $<0.05\left({ }^{\star}\right.$ Anova; ${ }^{\star *}$ not confirmed by LSD test; \#Kruskal-Wallis test; łChi squared).

have been evidenced in others Brazilian ${ }^{32-34}$ and international ${ }^{12,35}$ studies.

Such results, despite being numerically contradictory, lead to the reflection that economic situations minimally adequate guarantee an appropriate NPMD. It may also be that these infants already had their NPMD privileged by the school environment, since both daycare are appropriate sites. Moreover, taking in consideration that the research has started in the second school semester, it might be for this reason that the school environment had fulfilled its NPMD and few associations had been evidenced relating to the family income. Another hypothesis is that even if the relation between income and NPMD is recorded, there are critical periods in this association; considering that a longitudinal study ${ }^{12}$ reports this association to get stronger from 18 months, peaking at 4 years old, unlike the sample of this study which was composed with up to 18 months old infants. The lack of relationship between socioeconomic situation and infant development was also found by another Brazilian study with similar average economic situation ${ }^{36}$.

The infants's age in the study showed association with physical symptoms. For greater ages, higher score of physical symptoms, demonstrating that the biologic maturation is identified by this variable $e^{37}$.
Such associations were observed with the AIMS (with physical functioning) and Denver II (with cognitive functioning) of PedsQl ${ }^{\mathrm{TM}}$. Although it does not present a casual relation, it is interesting to reflect upon this linkage, for it may lead to think that the QoL's investigation, which is a multidisciplinary tool, may be used as choice and in cases of low scores, it may indicated necessity of specialized professional physical and motor evaluation.

The highest score in daycare was for the social interaction, perhaps because there was a suitable environment in the school for interpersonal relationships and stimulation from the teachers/ caregivers, although correlations have not been identified for this variable.

The association among emotional functioning with physical functioning, physical symptoms and cognitive functioning of PedsQL ${ }^{\mathrm{TM}}$, possible reflected a contextual model, for affection and emotions are initially built in the parental relationship ${ }^{38}$. They compose important experiences of the infants with themselves and others, and impact in their cerebral organization ${ }^{38}$.

The emotional aspects evaluated by PedsQL ${ }^{\mathrm{TM}}$ regard anger, crying, fear and agitation. Past the 5 first months, crying usually reflects the child's intention, who still cannot speak and needs to communicate with the caregiver somehow; it is 


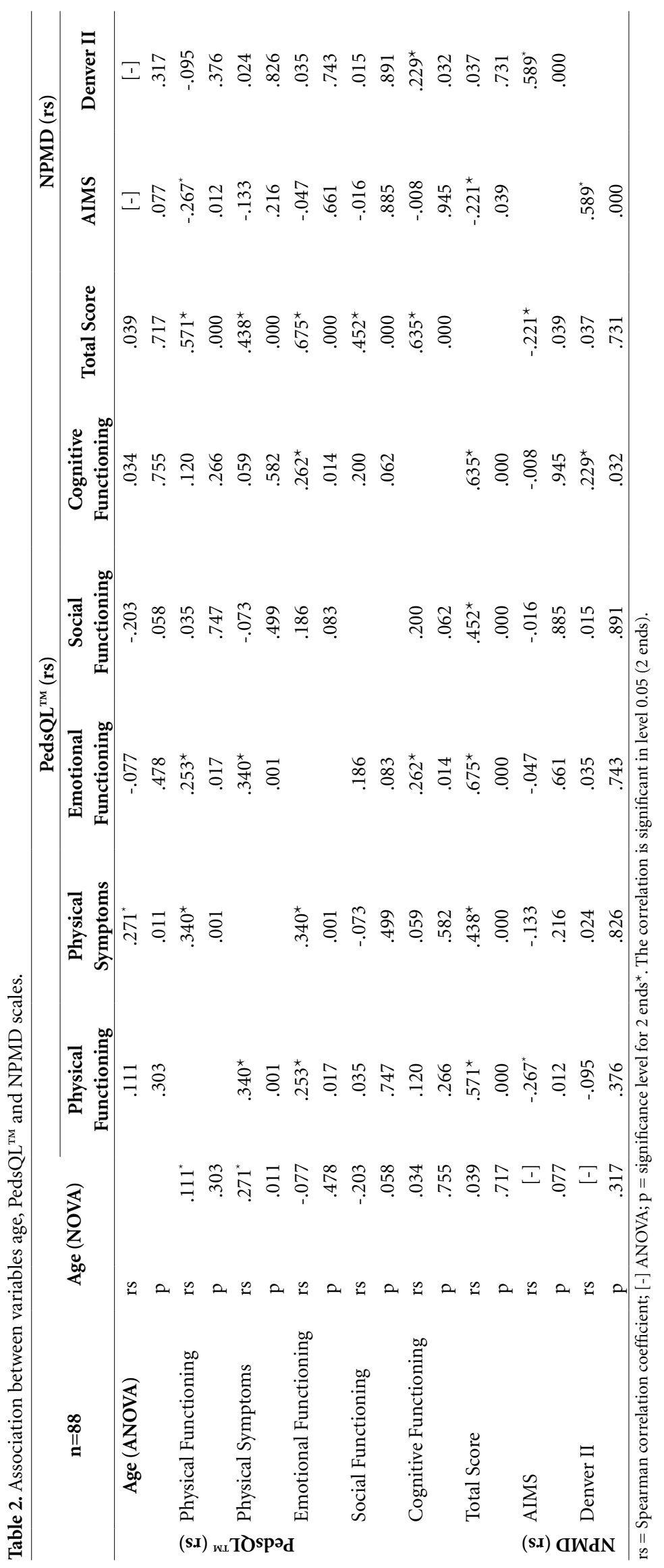


often understood as lack of emotional control ${ }^{39}$ and maybe, for this reason, obtained one of the worse scores, due to immaturity and language still on development.

It is likely that high values of interaction may be favored by the familiarity in the daycare, rules of the same that make parents to note a good interaction of their children with other people and infants, since they are the ones who answer to the survey, whereas lower values of emotional aspects are related to the attachment behavior, bond with their relatives, which tends to be higher than the attachment to the teacher/caregiver ${ }^{40}$, since usually among family, they retain all the attention in the house.

Most of the PedsQL ${ }^{\mathrm{TM}}$ items for the social interaction in the age group 1-12 and 13-24 are related to expressing a reaction to the presence, contact or action of someone else and not necessarily to only physical or verbal aspects. Lordelo ${ }^{41}$ reports that, in general, kids who frequent public daycare present a number of episodes of nonverbal interaction, with more physical contact other, than kids from private daycare, or in comparison to the home environment. It would be a profitable study to compare the QoL of infants who frequent daycares and ones who doesn't, to verify and make comparisons regarding the type of stimulation they've gotten.

As for the following items, physical functioning and physical symptoms are associated, probably reflecting upon the fact it is about healthy infants, and mostly with typical NPMD, even considering that the evaluation took place during winter in the south region of Brazil, where temperatures can be very low, time in which respiratory alterations are more recurring, mostly in infants ${ }^{42}$. The winter could have influenced lower QoL scores for emotional and cognitive functioning ${ }^{43}$ considering most of the infants were evaluated during winter.

It is interesting to observe that the physical functioning had no association with cognition different to a previous study performed ${ }^{44}$. The medium values related to cognitive functioning aspects in PedsQL ${ }^{\mathrm{TM}}$ were $67.92 \% \pm 21.13$, and showed big variability, as the items in this QoL scale involve mostly the child's capacity of imitation, and they use several brain areas for processing and execution.

Association, along with cause and effect relations had already been mentioned in studies with low social-economical level families, in which daycare had a protector effect in the development, favoring cognitive ${ }^{6,45}$ and future academic aspects, suiting even to diminish the development differences that are influenced by socioeconomic ${ }^{45}$ factors.

As expected, the total score of PedsQL ${ }^{\mathrm{TM}}$ was associated to all of its sub scores. Thus, although correlations with NPMD have been identified only for physical and cognitive functioning, the domains of PedsQL ${ }^{\mathrm{TM}}$ have correlated with each other, ratifying the complexity and interaction of several domains on infant development ${ }^{46}$.

The motor capacity is considered a good indicator for child development admeasurement ${ }^{47}$ and was confirmed by the relation of AIMS with physical functioning and total score of QoL by PedsQL ${ }^{\mathrm{TM}}$.

As it had been already expected in all daycares, it was found infants at risk or delay for the NPMD. The CEC 4, with lower family income and a lower score for physical functioning had more risk/delay for NPMD.

These results are in agreement to the nation$\mathrm{al}$ and international estimative for the delay in NPMD, which may vary from 2 to $11 \%^{48}, 3 \%{ }^{49}$ to $13 \%$ of children ${ }^{50}$ worldwide, $6.4 \%$ in $3-60$ months old Turkish children ${ }^{35}$, and of $13 \%$ of the North-American 9 to 24 months old children ${ }^{50}$. In Brazil studies indicate $24 \%$ of infants between 4-18 months on public daycare ${ }^{51}$ and $48 \%$ of Brazilian children up to 12 months old ${ }^{52}$ and up to $52.7 \%$ from 6 to 18 months old ${ }^{53}$, that probably get mixed to the estimative of disabled people, that is $10 \%{ }^{54}$. In that sense, national studies point that, for several reasons, the delay in DPNM may occur from $33 \% \%^{55}, 43.1 \%{ }^{56}$ to $52.6 \% \%^{57}$, mostly in older kids and evaluated by Denver II.

The infants evaluated by Denver II with risks to NPMD, presented delay mainly in social personal and language areas. Most of the Denver studies ${ }^{18,26}$ identify language delays as being the one with the highest occurrence of failures during evaluation. As reported, the relation between motherly contact and language development requires attention to the development of this aspect when considering the daycare environment.

In all likelihood, that happens because although these variables are labeled in dimensions, during the development many brain areas are utilized for more than one task, widening their connections through usage and end up influencing other activities that use similar areas ${ }^{44}$.

All of those studies indicate a multi-factorial nature for those delays ${ }^{26}$, confirming the necessity of verifying the impact in their life quality. To Drachler ${ }^{58}$, studies with high delay values could 
consist in overestimated numbers due to cut-off criteria considered demanding for this author, mainly for studies that use Denver II, even if its use is valid and worldwide used, and it allows to consider several aspects of NPMD. Maybe the lack of criteria in determining what is delay, as many infants with atypical development due to brain injuries and/or syndromes also are labeled in this nomenclature, would lead to this difficulty of real and more precise estimative in terms of prevalence ${ }^{21}$, considering that in this study no infants with neuromotor pathology has been considered, seeking to minimize the influence of characterization the QoL of typical infants and in risk to the NPMD.

Through and with movements, infants can express not only the neurological integrity and motor development, but also aspects of affection, cognitive and social interaction with the environment $t^{59}$. This association reinforces the necessity of monitoring of children in all aspects, by understanding and keeping up with the QoL, which means the comprehension of the impact and of the NPMD in a multifactorial way.

It is proposed monitoring verifying long term effects and the establishment of parameters through the use of PedsQL ${ }^{\mathrm{TM}}$, an easy applicable

\section{Collaborations}

TR Mélo: planning and execution of research, and main author. LB Araujo: execution of research and drafting of paper. B Yamaguchi: execution of research and drafting of paper. MP Ferreira: execution of research and drafting of paper. VL Israel: guidding, planning and execution of research, drafting of paper. tool that can identify several aspects related to the QoL.

\section{Conclusion}

To our knowledge, this is the first study to address the QoL of infants.

The infant's QoL with ages from 4 to 18 months old with typical development and/or in risk was considered adequate, with medium score in PedsQL ${ }^{\mathrm{TM}}$ of $76.93 \% \pm 9.00$, as the highest values related to social interactions and the lowest related to emotional and cognitive aspects.

Emotional functioning of infants in one of the four CECs was different; all other variables in Peds $\mathrm{QL}^{\mathrm{TM}}$ were similar among daycare centers. PedsQL's total score was associated with AIMS scores.

Besides, few researches propose to study infant's QoL, other than in a specific pathology group.

It is concluded with the study that the QoL evaluated by PedsQL $\mathrm{L}^{\mathrm{TM}}$ is associated with NPMD in 4 to 18 months old infants who frequent CEC for motor (with AIMS) and cognitive (with Denver II), which emphasizes the necessity of more studies to investigate the QoL of infants.

\section{Acknowledgements}

This study was financed in part by the Coordenação de Aperfeiçoamento de Pessoal de Nível Superior - Brasil (CAPES). 


\section{References}

1. Gaspar T, Matos MG, Ribeiro JLP, Leal I. Qualidade de vida e bem-estar em crianças e adolescentes. Rev Bras Terapias Cogn 2006; 2(2):47-60.

2. Colver A. Quality of life and participation. Develop Med Child Neurol 2009; 51(8):656-659.

3. Varni JW, Limbers CA, Neighbors K, Schulz K, Lieu JE, Heffer RW, Tuzinkiewicz K, MAngione-Smith R, Zimmerman JJ, Alonso EM. The PedsQL ${ }^{\mathrm{TM}}$ Infant Scales: feasibility, internal consistency reliability, and validity in healthy and ill infants. Qual Life Res 2011; 20(1):45-55

4. Fonseca M, Missotten P, Etienne A-M, Dupuis G, Lemétayer F, Spitz E. Children's Quality of Life Assessment: Child Quality of Life Systemic Inventory. Psicol Reflexão Crítica 2014; 27(2):282-290.

5. Campos D, Santos DCC. Controle postural e motricidade apendicular nos primeiros anos de vida. Fisioter Mov 2005; 18(3):71-77.

6. Christensen DL, Schieve LA, Devine O, Drews-Botsch C. Socioeconomic status, child enrichment factors, and cognitive performance among preschool-age children: results from the Follow-Up of Growth and Development Experiences study. Res Develop Disab 2014; 35(7):1789-1801.

7. Schobert L. O desenvolvimento motor de bebês em creches: um olhar sobre diferentes contextos [dissertação]. Porto alegre: Universidade Federal do Rio Grande do Sul; 2008.

8. Biscegli TS, Polis LB, Santos L, Vicentin M. Avaliação do estado nutricional e do desenvolvimento neuropsicomotor em crianças freqüentadoras de creche. Rev Paul Pediatr 2007; 25(4):337-342.

9. Setodji CM, Le V-N, Schaack D. Using generalized additive modeling to empirically identify thresholds within the ITERS in relation to toddlers' cognitive development. Develop Psychol 2013; 49(4):632.

10. Bonome-Pontoglio CF, Marturano EM. Brincando na creche: atividades com crianças pequenas. Estud Psicol (Campinas) 2010; 27(3):365-373.

11. Berticelli G, Henker CF, Roveda PO, Mayer VNK. Estudo do desenvolvimento neuropsicomotor de crianças nascidas prematuras. Saúde (Santa Maria) 2015; 41(2):139-148.

12. Mollborn S, Lawrence E, James-Hawkins L, Fomby P. When do socioeconomic resources matter most in early childhood? Adv Life Course Res 2014; 20:56-69.

13. Damiano DL. Rehabilitative therapies in cerebral palsy: the good, the not as good, and the possible. J Child Neurol 2009; 24(9):1200-1204.

14. Venturella CB, Zanandrea G, Saccani R, Valentini N. Desenvolvimento motor de crianças entre 0 e 18 meses de idade: Diferenças entre os sexos. Motricidade 2013; 9(2):3-12.

15. Gerzson LR, Catarino BM, Andara K, Demarco P, Palma MS, Almeida CS. Frequência semanal de um programa de intervenção motora para bebês de berçário. Fisio Pesqu 2016; 23(2):178-184.

16. Guimarães EL, Tudella E. Reflexos primitivos e reações posturais como sinais indicativos de alterações neurossensoriomotoras em bebês de risco. Pediatria (São Paulo) 2003; 25(1/2):28-35.
17. Santos D, Gonçalves V. Influência de práticas maternas no desenvolvimento motor de lactentes do $6^{\circ}$ ao $12^{\circ}$ meses de vida. Rev Bras Fisioter 2006; 10(2):225231.

18. Brito CML, Vieira GO, Costa MCO, Oliveira NF. Neuropsychomotor development: the Denver scale for screening cognitive and neuromotor delays in preschoolers. Cad Saúde Pública 2011; 27(7):1403-1414.

19. Associação Brasileira de Empresas de Pesquisa (ABEP). Critério de classificação econômica Brasil [Internet]. 2015 [cited 2016 Abr 17]. Available from: http://www.abep.org/criterio-brasil

20. Kruse S, Schneeberg A, Brussoni M. Construct validity and impact of mode of administration of the Peds$\mathrm{QL}^{\mathrm{TM}}$ among a pediatric injury population. Health and quality of life outcomes. 2014; 12(1):168.

21. Dornelas LF, Duarte NMC, Magalhães LC. Atraso do desenvolvimento neuropsicomotor: mapa conceitual, definições, usos e limitações do termo. Rev Paulista Pediatr 2015; 33(1):88-103.

22. Drachler ML, Marshall T, Carvalho Leite JC. A continuous scale measure of child development for population-based epidemiological surveys: a preliminary study using Item Response Theory for the Denver Test. Paediatr Perinatal Epidemiol 2007; 21(2):138153.

23. Frankenburg WK, Dodds J, Archer P, Bresnick B, Maschka P, Edelman N, et al. Manual técnico (Adaptação brasileira). In: Sabatés ALT, editor. The Denver II: a major revision and restandardization of the Denver Developmental Screening Test. São Paulo: Hogrefe; 2018.

24. Rydz D, Shevell MI, Majnemer A, Oskoui M. Developmental Screening. J Child Neurol 2005; 20(1):4-20.

25. Souza SC, Leone C, Takano OA, Moratelli HB. Desenvolvimento de pré-escolares na educação infantil em Cuiabá, Mato Grosso, Brasil. Cad Saúde Pública 2008; 24(8):1917-1926.

26. Araujo LB. Análise do desenvolvimento neuropsicomotor de crianças de zero a três anos em centros de educação infantil [dissertação]. Curitiba: Universidade Federal do Paraná; 2013.

27. Darrah J, Bartlett D, Maguire TO, Avison WR, Lacaze-Masmonteil T. Have infant gross motor abilities changed in 20 years? A re-evaluation of the Alberta Infant Motor Scale normative values. Develop Med Child Neurol 2014; 56(9):877-881.

28. Manacero S, Nunes ML. Avaliação do desempenho motor de prematuros nos primeiros meses de vida na Escala Motora Infantil de Alberta (AIMS). Jornal Pediatr 2008; 84(1):53-59.

29. Almeida KM, Dutra MVP, Mello RR, Reis ABR, Martins PS. Validade concorrente e confiabilidade da Alberta Infant Motor Scale em lactentes nascidos prematuros. Jornal Pediatr 2008; 84(5):442-448.

30. Saccani R. Validação da Alberta Infant Motor Scale para aplicação no Brasil: análise do desenvolvimento motor e fatores de risco para atraso em crianças de 0 a 18 meses [dissertação]. Porto Alegre: Universidade Federal do Rio Grande do Sul; 2009.

31. Vieira S. Introdução à bioestatística. Rio de Janeiro: Elsevier Brasil; 2015. 
32. Defilipo ÉC, Frônio JS, Teixeira MTB, Leite ICG, Bastos RR, Vieira MT, Ribeiro LC. Oportunidades do ambiente domiciliar para o desenvolvimento motor. Rev Saúde Pública 2012; 46(4):633-641.

33. Amorim RC, Laurentino GE, Barros KM, Ferreira AL, Moura Filho AG, Raposo MCF. Family health program: proposal for identification of risk factors for neuropsychomotor development. Braz J Physical Therapy 2009; 13(6):506-513.

34. Guimarães AF, Carvalho DV, Machado NÁA, Baptista RAN, Lemos SMA. Risco de atraso no desenvolvimento de crianças de dois a 24 meses e sua associação com a qualidade do estímulo familiar. Rev Paulista Pediatr 2013; 31(4):452-458.

35. Demirci A, Kartal M. The prevalence of developmental delay among children aged 3-60 months in Izmir, Turkey. Child Care Health Dev 2016; 42(2):213-219.

36. Zago JTC, Pinto PAF, Leite HR, Santos JN, Morais RLS. Association between neuropsychomotor development and biological and environmental risk factors in early childhood children. Rev CEFAC 2017; 19(3):320-329.

37. Rook GA, Lowry CA, Raison CL. Hygiene and other early childhood influences on the subsequent function of the immune system. Brain Res 2015; 1617:4762.

38. Mendes D, Pessôa LF. Comunicação afetiva nos cuidados parentais. Psicol Estud 2013; 18(1):15-25.

39. Barr RG. O choro e sua importância para o desenvolvimento psicossocial da criança [Internet]. Enciclopédia sobre o Desenvolvimento na Primeira Infância; 2011 [cited 2016 Abr 17]. Available from: http://www.enciclopedia-crianca.com/choro/segundo-especialistas/o-choro-e-sua-importancia-para-o-desenvolvimento-psicossocial-da-crianca

40. Melchiori LE, Alves ZMB. Comportamento de bebês em situações de separação e reencontro com os pais, na rotina diária da creche. Paidéia 2000; 10(18):51-59.

41. Lordelo ER. Interação social e responsividade em ambientes doméstico e de creche: cultura e desenvolvimento. Estud Psicol 2002; 7(2):343-350.

42. Guimarães PRB. Estudo sobre as relações entre as doenças respiratórias e a poluição atmosférica, variáveis climáticas e áreas verdes, na Cidade de Curitiba, $\mathrm{Pa}$ raná, Brasil [tese]. Curitiba: Universidade Federal do Paraná: 2011.

43. Asano R, Tsuchiya KJ, Harada T, Kugizaki Y, Nakahara R, Nakayasu C, Okumura A, Suzuki Y, Takagai S, Mori N, Takei N. Season of Birth Predicts emotional and Behavioral regulation in 18-Month-Old infants: hamamatsu Birth cohort for Mothers and children $(\mathrm{hBc}$ study). Frontiers Public Health 2016; 4:152.

44. Pereira KRG, Saccani R, Valentini NC. Cognition and environment are predictors of infants' motor development over time. Fisioter Pesq 2016; 23(1):59-67.

45. Laurin JC, Geoffroy M-C, Boivin M, Japel C, Raynault M-F, Tremblay RE, Côté SM. Child care services, socioeconomic inequalities, and academic performance. Pediatrics 2015:136(6):1112-1124.

46. Araujo LB, Mélo TR, Israel VL. Low birth weight, family income and paternal absence as risk factors in neuropsychomotor development. J Human Growth Dev 2017; 27(3):272-280.
47. Guimarães FAB, Assis CD, Vieira MEB, Formiga CKMR. Avaliação de material didático elaborado para orientação de cuidadores e professores de creches sobre o desenvolvimento infantil. Rev Bras Cresc Desenv Humano 2015; 25(1):27-40.

48. Lowe L, McMillan AG, Yates C. Body Weight Support Treadmill Training for Children With Developmental Delay Who Are Ambulatory. Pediatr Phys Ther 2015; 27(4):386.

49. Shevell M, Ashwal S, Donley D, Flint J, Gingold M, Hirtz D, Majnemer A, Noetzel M, Sheth RD, Quality Standards Subcommittee of the American Academy of Neurology; Practice Committee of the Child Neurology Society. Practice parameter: Evaluation of the child with global developmental delay Report of the Quality Standards Subcommittee of the American Academy of Neurology and The Practice Committee of the Child Neurology Society. Neurology 2003; 60(3):367-380.

50. Rosenberg SA, Zhang D, Robinson CC. Prevalence of developmental delays and participation in early intervention services for young children. Pediatrics 2008; 121(6):e1503-e1509.

51. Moreira H, Lima AC, Vilagra JM, Melin MB. Um olhar da fisioterapia no atraso do desenvolvimento motor em creches públicas. Varia Scientia 2009; 9(15):27-34.

52. Navajas AF, Blascovi-Assis SM. Avaliação do comportamento motor de crianças. Rev Terapia Ocupacional USP 2016; 27(3):246-253.

53. Silva ÂCDd, Engstron EM, Miranda CT. Fatores associados ao desenvolvimento neuropsicomotor em crianças de 6 a 18 meses de vida inseridas em creches públicas do município de João Pessoa, PB. Cad Saúde Pública 2015; 31(9):1881-1893.

54. Figueiras AC, Souza ICN, Rios VG, Benguigui Y. Manual para vigilância do desenvolvimento infantil no contexto da AIDPI. Washington: OPAS; 2005.

55. Maria-Mengel MRS, Linhares MBM. Fatores de risco para problemas de desenvolvimento infantil. Rev La -Am Enferm 2007; 15(spe):837-842.

56. Ribeiro DG, Perosa GB, Padovani FHP. Fatores de risco para o desenvolvimento de crianças atendidas em Unidades de Saúde da Família, ao final do primeiro ano de vida: aspectos sociodemográficos e de saúde mental materna. Cien Saude Colet 2014; 19(1):215226.

57. Resegue R, Puccini RF, Silva EMK. Risk factors associated with developmental abnormalities among high-risk children attended at a multidisciplinary clinic. Sao Paulo Med J 2008; 126(1):4-10.

58. Drachler ML. Medindo o desenvolvimento infantil em estudos epidemiológicos: dificuldades subjacentes. J Pediatr (Rio J) 2000; 76(6):401-403.

59. Scola C, Bourjade M, Jover M. Social interaction is associated with changes in infants' motor activity. Socioaffect Neurosci Psychol 2015; 5:28256.

Article submitted 03/12/2017

Approved 16/10/2018

Final version submitted $18 / 10 / 2018$ 